\title{
CROSSING BOUNDARIES AND STATE-BUILDING: HARMONISATION AND TOLERANCE IN VIETNAMESE RELIGIONS
}

\author{
Vo Van Sen ${ }^{*}$ \\ University of Social Sciences and Humanities, Vietnam National \\ University - Ho Chi Minh City, No. 12, Dinh Tien Hoang Street, \\ District 1, Ho Chi Minh City, Vietnam \\ E-mail: senvv@hcmussh.edu.vn \\ Nguyen Ngoc Tho ${ }^{* *}$ \\ University of Social Sciences and Humanities, Vietnam National \\ University - Ho Chi Minh City, No. 12, Dinh Tien Hoang Street, \\ District 1, Ho Chi Minh City, Vietnam \\ E-mail:ngoctho@hcmussh.edu.vn
}

Published online: 15 July 2020

To cite this article: Vo, V. S. and Nguyen, N. T. 2020. Crossing boundaries and statebuilding: Harmonisation and tolerance in Vietnamese religions. International Journal of Asia Pacific Studies 16 (2): 59-83. https://doi.org/10.21315/ijaps2020.16.2.4

To link to this article: https://doi.org/10.21315/ijaps2020.16.2.4

\begin{abstract}
Vietnam is a multi-ethnic state that has diverse religious traditions as a result of the continuous interaction of both internal and external sources of philosophies. Because of the demands and interests of the state and people, bureaucrats, elites and commoners of traditional Vietnamese kingdoms had to create a dynamic, unified system of notations and rituals in order to produce a shared political and cultural experience. Vietnam's struggle for independence and development during the last millennium has demonstrated that this system is a unique mechanism used to empower the Vietnamese people and enable the crossing of boundaries. History has shown that Vietnamese people, largely influenced by external philosophies, have learned to absorb and reconstruct a harmonised and localised form of ancestorworship and the Three-Teachings (Buddhism, Confucianism and Taoism) to create the cultural nexus for themselves. As a result, the fusion and reconstruction of national identity not only made Vietnamese culture more distinct from Chinese culture (a source of influence) but also created a neutralised social bond among


the different classes that strengthened the sense of solidarity. The people's war against foreign invaders, the people's diplomacy, and people-oriented policies were thus successful. The Vietnamese approach to state-building has sought to directly cultivate social harmonisation and religious tolerance among its people. This research mainly applies Adam Seligman and Robert Weller's (2012) concept of mutual interaction between notation, ritual and shared experience, in order to analyse different discourses disclosed by the case studies. The research argues that definite state-centralised agenda had never achieved the ultimate goal of statebuilding in Vietnam even though to some extent it appeared to have been successful during late imperial China. Instead, there always have been needs to find a neutral area somewhere in between both sides such that state interests and the desires of the commoners could meet, mutually make compromise and allow themselves to be fused together.

Keywords: Vietnam, ritual, shared experience, harmonisation, tolerance

\section{INTRODUCTION}

Vietnam is predominantly a rice-based agricultural society. As a Southeast Asian country, Vietnam has been influenced by Indian, Chinese and Western cultures (Phan 2006). The amalgamation of internal and external influences may make one believe that Vietnamese society and culture are full of contradictions, boundaries and ambiguities. This assumption, though, is incorrect. Vietnam has attained a highly integrated culture in both sacred and profane domains. The integration of different cultures in Vietnam was initiated by bureaucrats and elites, whose state-building approach distinguishes itself from China's approach to cultural integration, what James Watson called, "standardisation." In other words, Vietnam's long history of anti-sinicisation during late feudal dynasties and de-sinicisation in the era of French occupation has taught and pushed Vietnamese people to stand together, regardless of social and religious differences. Bureaucrats, under the direction of the elites, had strived to benefit from such a consciousness by transforming desinicisation into a source of harmonisation and tolerance rather than a source of nationalism. External threats created the driving force for internal solidarity that empowered Vietnamese people to confront these dangers.

Traditional Vietnamese civilisation adopted the Chinese model of statecraft. This model has produced many similarities between Vietnamese and Chinese culture. In researching how late imperial Chinese emperors built their state, Watson proposed the famous theory of "standardisation," which he defined as "state aided by the literate elite sought to bring locals under 
its influence by co-opting certain popular local deities and guaranteeing that they carried all the right messages[:]... civilization, order, and loyalty to the state" (Watson 1985: 323). Historically, late imperial Chinese emperors sanctioned the standardisation of gods, cults and rituals with the aim that "ritual orthopraxy served as a powerful force for cultural homogenization" (von Glahn 2004). Stephan Feuchtwang called this "imperial metaphor" (Feuchtwang 1992) and Prasenjit Duara called this "superscription" (Duara 1988: 778-795) to describe the mechanism by which the state privileges certain interpretations and sanctioned images to strengthen its control over society and integrate different cultures. Paul Katz also claimed that "how cultural integration in China was attained via the standardization of culture, here defined as the promotion of approved deities [...] by state authorities and local elites" (Katz 2007: 71-90). The state-sanctioned symbols "produced a high degree of cultural unity, transcending social differences in mythic interpretation and variant local ritual practice" (Sutton 2007: 5), hence each sanctioned cult functioned as "a channel whereby the state might be brought into the village" (Faure 1999). Chinese culture was thus highly integrated. Here, the state's co-option of certain popular deities, rituals and cults defines China's top-down approach of unifying different local cultures but at the same time exacerbated the social and class hierarchy.

However, compared to Chinese feudal dynasties, Vietnamese feudal dynasties were neither as centralised nor as hegemonic as their Chinese counterpart. On the one side, Vietnam had to confront the asymmetric power relationship with China, and on the other side, she had to unify her people to build the state and define their identity. Although considered a periphery state by China, Vietnam was also a "mini-centre" during the late feudal dynasties. This position ensured relative independence for Vietnamese culture, and it also served to subvert Chinese dominance. From his comparative case study of Yunnan and Vietnam, C. P. Fitzgerald found an interesting fact: "Vietnam has been sinicized much deeper and earlier than Yunnan, but it had never willingly accepted a Chinese identity and had maintained its own distinct Vietnamese identity [...]. The kings of Nanchao (Yunnan) sought to increase their power by seizing parts of the (Chinese) empire; the kings of Vietnam turned on their non-Vietnamese neighbors to the south and despoiled them of their possessions." In other words, Nanchao fought to maintain their distinct nonChinese character, "and prepare[d] the way for full Chinese authority"; while the Vietnamese learned to advance the frontiers, "bringing Chinese culture as the advance proceeded, and to create a situation where the Vietnamese people gained a national identity which made further Chinese intrusion improbable, 
rare, and finally wholly discontinued" (Fitzgerald 1972: 213). How did the Vietnamese people manage to build and maintain their identity against such a background?

\section{DIVERSITY AND ITS MEDIATION}

The history of human civilisation shows that peoples have to live with difference and ambiguity due to the diversity in ways of living and thinking. Those who are members of groups that are usually kept separate from each other, gradually develop differences. Diversity is thus a deeply ingrained feature of the world. Many theorists and writers advocate for a pluralism in which people produce and use "a system of thought which recognizes more than one ultimate principle" (Ellis 2015: 232). It is true that ambiguity appears when people make distinctions. Vietnamese bureaucrats, elites and commoners have always made the distinction with Chinese identity, and as a result, they create and confront ambiguities. It is a fact that any creation of order or imposition of boundaries and categories produce ambiguities. They are a feature of order, not chaos. Ambiguities exist even in the case when a specific religious group treats religious differences as though they were religious similarities. Arthur Wolf claimed that there was "a vast gulf between the religion of the elite and that of the peasantry" (Wolf 1974: 9); therefore, there exists many ways of understanding and manipulating liturgical rituals and symbolic philosophies of religions. In many cases, low tolerance for ambiguity correlates with "crude stereotyping, rigid defense and general lack of insight" that lead to ambivalence and warfare (Levine 1985; quoted in Seligman and Weller 2012: 19, 22).

According to Seligman and Weller, we can handle and cross boundaries by embedding "notation, ritual and shared experience" into our way of organising social activities. Those different aspects interact with each other which "helps to construct alternative historicities and socialities" (Seligman and Weller 2012: 9). If notation serves to order knowledge of the world, ritual and shared experience instead offer knowledge for the world (Seligman and Weller 2012: 204). Notation can be understood as a system of symbols used to represent patterns, elements or numbers in daily life. Notation attempts to impose a preconceived grid on experience - an interpretive template drawn from some ideal set of all similar previous experiences that will provide an ideal context and interpretive vision for it. During the process of Vietnamese nation building, people share a set of values where "they share the potential space of what 'could be,' a subjunctive world" (Seligman and Weller 2012: 
92, 150), the world that people "share the potential space of culture created through ritual" (Durkheim 1995). In another work, Seligman, Weller and their colleagues emphasised that "this shared 'could be' (or, sometimes, 'what if') is the nodal point where members of a society come together as symbol users." Similarly, they explained that the subjunctive world is the one which "creates a community of empathy at the same time." According to this interpretation, ritual, "therefore, is an endless work of creating a subjunctive world in overt tension with the world of lived experience" (Seligman et al. 2008: 23, 28).

Ritual means "primarily those acts that are formalised through social convention[s] and are repeated over and over in ways that people recognise as somehow the same as before." According to Emile Durkheim (1858-1917), many people tend to understand ritual as a channel to deal with the sacred world only; however, the basic structure of rituals is actually to cross the boundary between the sacred and profane (quoted in Seligman and Weller 2012: 7). Ritual repetition allows us to share disparate experiences together and to live with difference, not to remove it (Seligman and Weller 2012: 8-9, $25,94,134)$. Ritual can allow us to live with ambiguity even when we lack a full understanding.

Ritual impels a flow of time in a way that notation needs not. Any boundary crossing implies movement over time. Ritual regularises this through conventionalised repetitions - the constructed and shared rhythms that we call "meter." Ritual creates time in the sense that its shared meters allow people to feel that the world is not in total chaos, that what happened before can reliably happen again, that we share a past and a potential future (Seligman and Weller 2012: 201-202). "The attraction of pluralism," McGrath said, "lies not in its claim to truth, which is remarkably elusive and shallow, but in its claim to foster tolerance among the religions" (Okholm and Philips 1996: 208; quoted in Marbaniang 2007).

Shared experience can be understood as a form of highly contextualised knowledge by which participants together learn to embed (or to absorb) during a ritual or a significant event that enables them to cooperate across boundaries by reconciling differences (Seligman and Weller 2012: 161). This process can extend even to the point of not attempting to come up with shared meanings, as long as there is a sufficient sense of shared processes and shared goals for working together.

The process of shaping Vietnamese identity distinctly from its Chinese counterpart and the state-organised religious diversity both have always brought chaos. Richey once stated that "Confucianism is not seen as a Chinese tradition but rather as a native expression of Vietnamese values" 
(Richey 2013: 60), while O. W. Wolters took it cautionary when using the term "Confucianism" in Vietnamese cultural history (Wolters 1976: 203-226; cited in Duong 2004: 289). "The very ordering of chaos, however, creates its own ambiguity" which we cannot deny (Seligman and Weller 2012: 18). Ambiguity, in this case, is the price the Vietnamese pay for their need to draw [the/a] distinction with the Chinese; it required the people to live in a shared experience even though the state is full of ethnic and religious diversity. Ultimately, all bureaucrats, elites and commoners met in a place which may be called "empathy." Empathy develops generosity and sense of sharing among the participants. Under Chinese cultural dominance and the strong demand of creating a Vietnamese social and cultural structure, people of different classes moved closer together. Eventually, this social structure enabled religious harmony and tolerance in Vietnam.

\section{THE BUILDING OF SHARED NOTATION AND SOCIAL RITUALS IN VIETNAMESE CULTURE}

Specifically, notation and social rituals in Vietnamese culture are built upon two pillars: the spirit of religious harmony and tolerance (the internal factor), and the strong demand to build a state identity (the external factor). The former, as the prerequisite, lays the foundation for boundary-crossing, while the latter supplies the impetus that ensures the attempts at boundary-crossing are brought to completion.

As many Western writers emphasised, "to be a pluralist is to claim that the religious perspectives of more than one basic theistic system or variant thereof can justifiably be considered equally close to the truth" or "be considered to reflect some aspect of this truth" (Byrne 2011: 36-37). Neither the pluralist nor the inclusivist, however, can avoid exclusivism at some point. Theologically speaking, moderate exclusivism proves to be the best since it neither distorts the meaning of truth, as pluralism does, nor imposes itself on other religions, as inclusivism does, but remains true to its source of doctrine (Marbaniang 2007). During the process of state-building, the Vietnamese possessed the dualistic attitude of inclusiveness and exclusiveness when dealing with Chinese culture (and maybe with Western culture too); moreover, they are inclusive when rallying people of different classes together for statebuilding and identity-construction projects. Therefore, Vietnamese nationality stems from the need to confront external threats that in turn generates (or creates) an internal social structure that is both resourceful and adaptable. 
Externally, Vietnamese have always been worried about being ruled by outsiders (such as when the Chinese tried to rule Vietnam for more than ten centuries, from $111 \mathrm{BC}$ to $938 \mathrm{AD}$, and during the Ming occupation between 1407 and 1428) and being assimilated by a foreign culture; therefore, the state cultural structure has been shaped on a rather independent mode which is distinct from China.

Notation itself is related to cultural identity. Deeper notation can be clearly defined through the process that the nation-state draws/redraws boundaries and reconstitutes collectivities through a high degree of abstraction and notational interventions, such as bureaucracies, flags, literature, rituals, popular religions, etc. (for details, see Seligman and Weller 2012: 179). An independently perceivable system of cultural notation can make the distinction sharper and stronger.

The Vietnamese national identity was formed during the first period of Chinese rule. Australian scholar, Jennifer Holmgren, stated that "contemporary records of Chinese activities in Tonking during the first six centuries of colonization tell us more about the process of Vietnamisation among Chinese families than they do about Sinicisation of the Yue 越” (Holmgren 1980: 172). Accordingly, many Chinese clans established family interests in North Vietnam and were absorbed into the social, economic and political environment locally. Chinese Confucian culture strongly affected the Vietnamese bureaucracy and the elite during the Tang dynasty; however, it could not entirely assimilate the Vietnamese people into the Chinese culture. In turn, the Vietnamese, with their strong consciousness of national identity and ethnic distinction, started appropriating Chinese ideological and philosophical wisdoms to construct their own culture and source of power. Fitzgerald said, “...Vietnamese culture took on a deep Chinese coloration, but the ethnic character of the people continued to be Yue, that is 'Viet,' and they inherited and cherished that consciousness of difference in race and desire for separate nationhood which in a modified form has always characterized their more assimilated cousins, the Cantonese" (Fitzgerald 1972: 22). "If Chinese troops, stationed in the country, remained there after the political change, they became absorbed into and assimilated with the native race" (Fitzgerald 1972: 214). Similarly, Joseph Buttinger has elaborated further by claiming that the Vietnamese people "absorbed of the skills, customs, and ideas of the Chinese, the smaller grew the likelihood of their ever becoming part of the Chinese people" (Buttinger 1968). Truthfully, the Vietnamese people have got their own agenda for their own tradition. In fact, it was the Chinese emperors' intensive efforts to turn North Vietnam into Chinese territory during the 10-century-long period of Chinese occupation 
(BC 111 to AD 938) and then the 21-year period of Ming's rule (1407-1428) which pushed "the Vietnamese to become their own as a separate people with political and cultural aspects of their own" (Buttinger 1968: 29). As a long but narrow nation with diverse geographical conditions, the Vietnamese territory is "the most oddly shaped in the world." Such geographical conditions attract foreign invasions; therefore, "to be Vietnamese is to resist and suffer external oppression, but it does not require abstinence from the world's good things" (Womack 2006: 63). Baldanza, after investigating Sino-Vietnamese relation during early and middle Ming period, suggested the so-called "de-civilizing mission" among Chinese elites which "was a drive to classify the Vietnamese as culturally other, not as a precursor to converting them to Chinese way, but rather in order to draw a clear line between "us and them" and to demarcate a strict division between the two states" (Baldanza 2013: 56).

The bureaucrats and the elites led the process of state-building. Robert Weller said, "The elites tended to develop more ideologized religious interpretation..."; "community solidarity opposes or supports national solidarity as the national political situation improves or worsens" (Weller 1987: 10, 53). Driven by the strong desire of building a distinct national identity, the Vietnamese bureaucrats and elites actively strove to establish common interests and to connect individuals of different backgrounds by using a distinct set of cultural notation to construct shared rituals and a shared experience. Vietnamese first civil law, the Le dynasty's Hong Duc Code (1430s), is said to be a civil law. Through this code, the Le government wished to "protect independent villages from being absorbed into larger private holdings [to] keep social levels, such as those of dependents ('serfs') and commoners, stable and separate from private interests" (Dutton and Werner 2012: 126).

Internally, Vietnam is the living land of many world religions and ideologies. Approximately around the beginning of the Christian era, Indian Theravada Buddhism was disseminated in North Vietnam while both Buddhism and Brahmanism were disseminated in Central (Champa culture) and South Vietnam (Oc Eo culture). Theravada Buddhism was then replaced by Chinese-styled Mahayana Buddhism, Confucianism and Taoism during the period of Chinese occupation (111 BC-938 AD). Catholicism, on the other hand, arrived in Vietnam as early as the 1560s after the Western traders (Portuguese, Italian, French, etc.) proselytised Vietnamese coastal communities (Tran 2001: 522; Phan 2010). Catholicism has since spread throughout the nation when Vietnam began enlarging their territory to the 
central and southern part of the country between 16th and 19th centuries. After the introduction of Catholicism, Protestantism has also been propagated throughout Vietnam. The process of unifying the central and the southern lands from the early 17th century onward allowed the Vietnamese people to absorb the ethnic Cham's Brahmanism and Islam as well as the ethnic Khmer's Theravada Buddhism. The arrival of the Chinese people during late Ming to early Qing period in Southern Vietnam also enriched the religious diversity in Vietnam through their popular religions (polytheism) and folk Taoism, such as the cults of Tianhou 天后, Guandi 關帝, God of Wealth 福 德正神 and other popular gods. The southern Vietnamese started creating new religions by reconstructing existing ones in the late 19th and early 20th century by absorbing the attractive qualities of all religions and philosophies together and rebuilding them under a new ideological framework. Hue-Tam Ho Tai (1983) stood on the perspective of political history to call this the millenarian movement. There were several millenarian sects that were founded during this period, among which includes Buu Son Ky Huong, ${ }^{1} \mathrm{Tu}$ An Hieu Nghia $^{2}$ and Hoahaoism ${ }^{3}$ in An Giang province, Caodaism ${ }^{4}$ in Tay Ninh, and other popular religious movements. Research by Truong Van Chung in 2016 shows that more new religions, such as Yi Kuan Tao (一貫道), ${ }^{5}$ Jehovah's Witnesses, ${ }^{6} \mathrm{Minh} \mathrm{Su}^{7}$ and $\mathrm{Ha}$ Mon, ${ }^{8}$ etc. are either disseminated or founded recently in Vietnam (Truong 2016: 450-595). In his analysis, Truong Van Chung stated that new religions are created and propagated under the notion of the self-experience capacity, secularism and strong sense of changeability and adaptation, pragmatism (reality-based practices) and religiosity (Truong 2016: 674-677). Many millenarian leaders, as well as newly-emerging sect organisers, have taken advantage of an obvious feature of Vietnamese personality to form their religious foundation - religious harmonisation and tolerance.

During the middle and late feudal dynasties, Vietnamese kings and the elites learned to organise commoners through harmonising Confucianism, Buddhism and Taoism - each inclusively intertwined with the others (see also Ho Tai 1983: 20). As analysed by Rodney L. Taylor, Confucianism has got a "single thread runs throughout the tradition, and this thread is religious" (Taylor 1990: 2). This primary attribute has laid the basic foundation for the conflation of "Three Teachings." Indeed, the "Three Teachings" formed a syncretic belief system that integrates Buddhist, Confucian and Taoist tenets that could be found at all levels of Vietnamese society (Dutton and Werner 2012: 114; Duong 2004: 289-318). 
Vietnamese society and culture have accumulated and incorporated internal and external influences, in which "the ideologies of the spirit cults, Buddhism, and classical Confucianism continued to interact within the royal court and village society" (Dutton and Werner 2012: 31). All the classes merged these three teachings together; however, people tended to prefer one teaching over the others depending upon the circumstances of their lives. The rulers tended to use Confucianism to organise and run the state, and they used Buddhism and Taoism to connect and incorporate people to the state structure. Ho Tai (1983: 20) concluded that "Confucianism absorbed in governmental operation and associated with the scholar-officials while both Taoism and Buddhism loomed larger in the daily life of the average Vietnamese."

Confucianism strongly emphasises the concept of harmony. Early Chinese Confucians, in fact, theorised the core idea that ritual was the key to creating harmony. According to Analects 1.12, Confucius himself argued that "among the functions of $l i$ (禮), the most valuable is that it establishes harmony" (Waley 1938: 12). Chinese and Vietnamese emperors acknowledged and regulated annual sacrifices to the Heaven, Earth and specific state gods to ensure the maintenance of state harmony. The responsibility of the Ministry of Ritual was to solve these issues. Sometimes, the king directly ordered people of reputation to be responsible for consolidating and regularly implementing li to ensure the social order, such as King Le Thai To (1428-1433) who ordered the sage, Nguyen Trai, to determine the system of court dress, headgear, annual state, village and family rituals as well as musical arrangements for each occasion (Dutton and Werner 2012: 107). The significant difference between the Vietnamese way of defining social rituals and imperial Chinese "standardised orthopraxy" (as defined by Watson 1985: 269-310) is that Vietnamese kings and bureaucrats fused both top-down and bottom-up approaches, i.e., state-driving aims with commoners' desires. Confucianism states, the "superior man harmonizes without being the same, the inferior man is the same without harmonizing" (Waley 1938: 23). The Vietnamese bureaucrats, elites, and at some extent, the commoners in all historical periods have learnt from this lesson, they put aside or concealed the domestic difference (or conflict, if any) for the ultimate goal of national peace and development. Obviously, localised Confucianism has contributed to the state-building process in Vietnam. Additionally, it is necessary to note that Vietnamese Confucianism was profoundly transformed from classical doctrines (N. T. Nguyen 2016) to one that coexisted and interacted with indigenous cults and Buddhism (see also Dutton and Werner 2012: 35). Dung N. Duong once suggested that Vietnamese Confucianism "should be realized in conjunction with Buddhism and Daoism" (Duong 2004: 294). 
Similarly, Mahayana Buddhism in Vietnam strives for social harmony. With a large portion of the state population claimed to be Buddhists, Vietnam is a Buddhist state. After a long period of Chinese rule (111 BC-938 AD), the Ly dynasty (1010-1225) and Tran dynasty (1225-1400) strongly promoted Buddhism as the country tried to reshape state identity differently from the Chinese model (see Buttinger 1972: 41; Taylor 1976: 172-176). Lee Khoon Choy stated that Ly and Tran dynasties were stable periods when Vietnamese "molded a Southeast Asian Vietnamese culture" (Lee 2013: 336-337). At the end of Tran dynasty, while classical Confucianism was growing, the royal family, bureaucrats and commoners became interested in Chan Buddhism, especially the Truc Lam School (See Dutton and Werner 2012: 30). Later dynasties also proved to be more enthusiastic about Buddhist philosophy. The Nguyen lords in the state of Quang Nam (later to be called Cochinchina by the French colonists) had an agenda to empower the state to compete against the Confucianised Tonkin state by inviting many famous Chinese monks (such as Nguyen Thieu/Yuan Shao 元韶, 1648-1728; Thich Dai San/Shi Dashan 石大汕, 1633-1705, etc. (see H. D. Nguyen 1995: 91-93, 126-128, 166-168) to help develop Buddhism as an official religion in the country. Thanks to these concrete foundations, the Vietnamese nation has been fostered its unification. John Whitmore stated that "Vietnam was a land of many temples and famous monks, and its hold on the Vietnamese people seems to have been fairly strong." "Taoism, on the other hand, was not nearly as entrenched, though a number of its temples did exist" (Whitmore 1985: 120). We suggest that the Vietnamese used Buddhism to unify the new territories in the South, since both the local Khmer and overseas Chinese population normally practiced Buddhism. ${ }^{9}$

Consequently, the never-ending process of molding Vietnamese identity and building religious harmonisation has constructed the sense of rationalism and tolerance. As a result, the ordinary Vietnamese person is usually friendly, open-minded, generous and tolerant. Since 1633, Christoforo Borri remarked, "The Cochin-Chinois ${ }^{10}$ is more gentle and courteous in conversation, than any other nation of the East: and albeit on the one side they stand much upon their valour; yet on the other side, they hold it as infamous to be transported with choler," and concluded that "By which occasion, there is a fair Gate opened for the Preaching of the Gospel of Jesus Christ amongst them." Later, C. Gosselin remarked "the Annamese are gentle and harmonious, easy to listen to the right reason and strongly condemn the agitation of anger" (Gosselin 1904: 526). Paul Giran further remarked that Vietnamese have a moderate mind, meaning that in them all elements are in harmony and balanced with 
each other (Giran 1904: 64). After conducting quantitative and qualitative research, Tran Ngoc Them found that contemporary Vietnamese express a stronger sense of equanimity, optimism, pragmatism, creativeness and critical adaptiveness (Tran 2001: 211-233).

Besides harmonising differences and diversity, the Vietnamese are strongly influenced by sentimentalism and theory of yin-yang interaction which allow them to apply a flexible behaviour and avoid extremism in action (see Tran 2001). During the first millennium AD, while being ruled by Han Chinese leaders, Vietnamese people sought for their own spiritual supports; eventually they got inspired by Buddhism. Their minds, their feelings and their spirits were profoundly deepened by Buddhist thoughts. They continued absorbing Confucian and Taoist philosophy from a foundational understanding of Buddhism and reconciled them under a Vietnamese prism (Phan 2010: 27-106), creating a harmonious spiritual life. Starting from Buddhism, the Vietnamese style further adopted "Tam giáo đồng nguyên" (The Three Teachings are of the same original source /三教同源) from classical Chinese tradition and continued developing it into "The myriad teachings have the same original source" (萬教同源) and/or "Tam giáo hợp nhất" (The unity of Three Teachings /三教合一). Dung N. Duong also asserted that Confucianism, together with Taoism, had to accommodate themselves to Buddhism (Duong 2004: 300). It is religious harmony and flexibility that foster religious tolerance. Paul Giran (1904) said, "The special feature of Vietnamese belief is the tolerance" (Giran 1904: 200). Buddhism itself highly values the concept of "Advaita" (nondualistic), meaning "not to differentiate from the other under any form" (T. N. Nguyen 2016: 122) However, the Vietnamese overestimate this spirit. This harmonious spirit regulates daily behaviour as well as social life. The author, Nguyen Thua Hy, quoted Crawfurd's statement that Vietnamese people "love to laugh, are witty, like to talk, and are hospitable and easy-going" (see T. H. Nguyen 1994: 65). Nguyen Van Huyen's research emphasised “(Vietnamese) are eager for hospitality and generosity. They can treat their friends to a very tasty meal and even live in poverty for many days with their wife and children" (V. H. Nguyen 1996: 560). As a matter of fact, Vietnamese people are keen on stability, harmonisation, tolerance, sentimentalism, emotion, poetry, patience and hospitality (see Phan 2010). The harmonious Vietnamese mind and easygoing manner are surely not simple shallow-mindedness. 


\section{THE FORMATION OF SHARED EXPERIENCE AND ITS EFFECTS IN VIETNAMESE CULTURE}

Shared experience, in its repetitive circulation, can create the empathy and sense of inclusiveness among the members of a group. Hans-Georg Gadamer said, "Experience is valid only if it is confirmed; hence its dignity depends on its fundamental repeatability" (Gadamer 1975 [1960]: 311). Experience, thus, has to be validated by repetition. Vietnamese feudal leaders and elite members were conscious about this principle. Hence, they started building many annual and periodical sacred sacrifices, ceremonies, codes of behaviour and other notational complexes to nurture the "communitas" experience among state members.

Vietnamese people create a shared experience, one that is mediated through ancestor-worship, hero-worship ${ }^{12}$ and the "Three Teachings." Each one mediates order and disorder in each sphere: ancestor-worship deals with family and family-based relations, the "Three Teachings" help build harmonious social relationships, and hero-worship directly promotes the national solidarity and identity-building. As mentioned above, when confronting difficulties in the state-building process or uniting the people, the Confucianised Nguyen lords in the early 17th century invited several Chinese monks to Vietnam to unify the people. Buddhism, in its turn, existed and developed on the axis of multi-religious harmonisation. After Chinese monks moved to Vietnam, they had to transform their meditation practices and liturgy in order to be accepted (in Vietnam); therefore, the Buddhism that both Chinese and Vietnamese monks generated evolved differently from the Buddhism in China (H. D. Nguyen 1995: 92). Similarly, ancestor-worship and Buddhism are still practiced among the ethnic Chinese communities in Vietnam; they are an effective means in implementing the process of integration and indigenisation (N. T. Nguyen 2017).

Vietnamese identity is perpetually changing. It is not a well-defined or well-constructed set of values. The long but narrow territory with diverse topographic expressions, diverse climatic zones with harsh oceanic typhoons and unpredictable tropical monsoon, all have trained the Vietnamese people to possess a sense of critical interaction and adaptation. Vietnamese love living in peace in their homeland, but their critical sense of adjustment and adaptation brings them mobility. Vietnamese people are considered to be flexible, openminded and easy-going. They are not xenophobic. Brantly Womack said, "there is no dimension of Vietnamese life or culture that simply curls up within Vietnam and shuns the outside world." To be creative in music, art, 
cinema, cuisine or literature means to be engaged in a cosmopolitan space in which anything that is useful is good. To be cosmopolitan, to learn languages, to travel or to swim competently in world currents is not to be less Vietnamese. Americans visiting Vietnam over the past 25 years are usually struck by the fact that "Vietnamese do not appear resentful about the war" (Womack 2006: 64-65). Vietnamese identity contains the spirit of multicultural harmonisation and tolerance. Ancient and medieval maritime trade lines took many parts of Vietnam their seaports and stop-overs. The excavation of the Oc Eo sites in the Mekong River Delta and the findings of many Roman coins (some date back to the time under the reign of Antoninus Pius (138-161 AD) and some under the reign of Marcus Aurelius (161-180 AD), and while other relics have been unearthed (Tran 2001: 521; Vo and Pham 2017: 61) reveal that ancient Roman and Middle Eastern traders once traded in Vietnam. In the first millennium AD, Vietnam was once ruled by the Han Chinese (111 BC-938 AD). Chinese rulership could not stop the dissemination of Confucianism, Mahayana Buddhism and Taoism. Phan Ngoc, a well-known Vietnamese researcher, emphasised that the Vietnamese people creatively and simultaneously applied four prisms, namely nationalism, destiny, rural village-based living environment and Southeast Asian culture, to deal with Chinese philosophies and religions; this helped the Vietnamese to absorb and use these introduced wisdoms in their own way (Phan 2010: 27-106).

The religious tolerance in Vietnam cultivates the harmonious society with distinctive identity and cultural characteristics. Vietnamese civilisation is mainly inclined to intellectual civilisation rather than an institutional one. Many Buddhists understand and apply Confucian and Taoist philosophies to their liturgical activities. As a result, Confucian scholars and Taoist masters never prohibited the practice of Buddhism. Many Confucian scholars were inspired by their visits to Buddhist temples. Their personal interactions with Buddhist monks allowed for the osmosis of Confucian and Buddhist philosophy (see D. L. Nguyen 2007). The feudal educational system was also deeply inspired by "The Three Teachings are of the same source." Five years after the Temple of Literature was built in the ancient capital, Thang Long (presentday Hanoi), King Ly Nhan Tong organised the first Three-Teaching Imperial Examination to choose the best scholars from the country. The Vietnamese historian of the ancient period, Ngo Si Lien (15th century) wrote, "ThreeTeaching Imperial Examination seeks to find scholars who are comprehensive in all three philosophies to become officers" (Ngo 1697 [2006]). Phan Huy Chu (1782-1804) stated: "Ly and Tran dynasties, both highly appreciated Buddhism and Taoism; therefore, they selected intellectuals who specialize 
in both philosophies... The talented scholars, though, specialized in all three teachings" (Phan 1961: 54)

In fact, the idea of "The Three Teachings are of the same original source" (三教同源) became available during the period of Chinese occupation and was probably imported from China. Thich Minh Tue, a Buddhist master (1993), quoted the case of Mou-zi (牟子) arriving in Vietnam from China at the end of 2nd century AD. Mou-zi expressed in Ly Hoac Luan (理惑論) ${ }^{13}$ that after his mother's death, he did not want to work as a mandarin. Instead, he indulged himself in the three-philosophies. He applied his understanding within Buddhism, pondered on Lao-zi's Daodejing, took Taoist miracles as "good wine" and Confucian classics as "the flutes" (Thich 1993: 68). In the Le-Nguyen period (15th-mid 20th centuries), Confucianism was established as the national ideology. Confucian scholars became entangled by the unchanging Confucian principles, however, they actively learnt from Buddhist and Taoist philosophies to enhance their capacity of dealing with people and to keep balanced between their political and social life. Nguyen Trai (1380-1441), Ngo Thi Nham (1746-1803), Nguyen Dinh Chieu (18221888), etc., are well-known scholars in such a tradition.

As for family and social relations, feudal dynasties exaggerated the Confucian value of loyalty (忠) for their own purposes. However, based on the idea of religious harmonisation and tolerance, the concept of loyalty is built on the virtue of filial piety and righteousness. Loyalty is co-shared with filial piety; loyalty is practiced when the king and imperial class work in coherence with the people and for people's benefits. The ethics of loyalty, therefore, is closely tied to patriotism and the motto: trung quân -ái quốc. ${ }^{14}$ When loyalty expands patriotism, it also involves the concept of filial piety since this ethic is classified into two mutually interdependent values: normal filial piety and great filial piety (patriotism). In patriotism, the concept of righteousness becomes modified by loyalty and filial piety. Accordingly, righteousness itself is divided into normal righteousness and great righteousness (patriotism). As stated by Phan Ngoc (Phan 2010: 27-106), Vietnamese people see the world through their own prisms, among them, nationalism or patriotism has made Vietnam different from the other East Asian countries (Nguyen 2016).

Vietnamese people consider patriotism the most important virtue. "The Vietnamese are normally shy and peace-loving, however, when encountering dangers, they are willing to sacrifice for the great righteousness/ 大義” (Dao 1938: 342). Thanks to Vietnamese peace-loving and tolerant mindset, they are wise when dealing with resentment. In the early 15th century, after defeating the Chinese invaders, King Le Loi and scholar Nguyen 
Trai decided to set up boats and carriages and offered foods for the Chinese invaders to return to China (Ngo 1697/2006: 63-66).

Catholicism was transmitted in the middle of the 16th century and has continued to grow in size during the last four centuries. Vietnamese Catholics simultaneously worship God and their ancestors, live generously and tolerantly, and observe Confucian principles and Taoist naturalistic harmony. Their mottos, "Sống Phúc âm trong lòng dân tộc" (Live the gospel in the heart of the nation) and "Kính Chúa yêu nước" (Respect God and practice patriotism), deeply resemble traditional harmonisation and tolerance. During the Nguyen dynasty (1802-1945), the royal family and the mandarins discriminated against the Catholics, yet they remained faithful. In 1858, when the French attacked Da Nang and one year later, Sai Gon, they tried to attract the support of Catholic villages and communities; however, none of them followed the French. Vietnamese practice their original version of Catholicism that fuses patriotism, religious tolerance, and aspects of Buddhism, Confucianism and Taoism. Catholicism was found as an important philosophical factor in Coconut Sect ${ }^{15}$ as well as other religious movements.

There has been almost no religious warfare in Vietnamese history. In all cases, the Vietnamese people recognised that ideological differences were real and that, at least temporarily, they could be bridged. In the 1870 s, the Sat Ta Binh Tay movement broke out in Nghe An, Ha Tinh and other provinces in North and Central Vietnam; ${ }^{16}$ however, it was limited to small regions and short periods while the main reasons for the movement came from political clashes, not religions themselves. During the Vietnam War (1954-1975), Haohaoism in the Mekong River Delta was ordered by Ngo Dinh Diem, leader of the Saigon Regime, to organise an army; however, it became useless and disappeared at the end of the war. Recently, the riots in Hanoi (Thai Ha parish), Nghe An and Bac Giang province all were engaged in land-based and other social conflicts (Tran and Hoang 2014).

Religious movements in Southern Vietnam have expressed religious tolerance since the middle of the 19th century. The movements were in response to the French invasion of Vietnam and also an expression of original ethics and values: tolerance and flexibility. New religions were constructed from the concept of filial piety and patriotism after the long process of dismantling rigid Confucian concepts. Therefore, "in Southern Vietnam, the so-called 'Confucianism' is not Confucianism." Instead, "the so-called 'not Confucianism' is just Confucianism" (Cao Tu Thanh 1996: 147). ${ }^{17}$ Many people visiting Buddhist temples to worship Shakyamuni Buddha, Bodhidharma or Avalokiteśvara don't really know about the life of the 
Buddha or the stories of other important Buddhist figures. Similarly, "they practice Confucian principles daily but don't know who Confucius or Lao-tzu is. In their eyes, these classics must be used in their adaptable way" (Nguyen and Phan 1991: 64). It is the Mekong River Delta where Mahayana Buddhism reunites with its counterpart, Theravada Buddhism, through the ethnic Khmers, making Buddhism the core philosophy for almost all reconstruction processes that shape new religions. A pair of couplet attached at the main gate of the communal shrine of Thoai Son District in An Giang province, reads:

Quân phi quân thần phi thần quân thần giai cộng lạc;

Phụ bất phụ tử bất tử phụ tử thị đồng hoan ${ }^{18}$

Another case study comes from Minh Duc Nho Giao Dai Dao, ${ }^{19}$ a deconstructive version of classical Confucianism in Tra Vinh province (also in the Mekong River Delta). This sect was founded in 1932 by Luu Cuong Cang, a farmer from the Ba Dong coastline under the reconciliation of the decentralised Confucianism and the core values of Buddhism. On the other hand, Minh Duc Nho giao dai dao also added Taoist and Caodai philosophies in their moral principles. The followers worship three important values: minh đức - tân dân - chí thiện. “Minh đức" 明德 means “to illustrate illustrious virtue," “tân dân” 親 [新] 民means “to renovate the people," and "chí thiện" 至善means "to rest in the highest excellence." ${ }^{20}$ Actually, this is a specific expression of the original concept of Filial piety under the form of a millenarian sect in which Buddhism and Confucianism are intertwined. In summary, multicultural harmonisation and religious tolerance are the core values and philosophical foundation throughout history. They were constructed during the processes of treating specific natural environment locally and managing the social and international relations. Structural analysis has shown that multicultural harmonisation and religious tolerance imply social principles rather than religious miracles and mysteries. Above all, patriotism, righteousness, flexibility and open-mindedness are the most important values (moral aesthetics) that directly impact the process of shaping multicultural harmonisation and religious tolerance. This process helps make religions and religious basis in Vietnam more rationalistic and science based as well as make Vietnamese identity an everlasting process rather than a defined set of aesthetics and values.

It is true that the state, the law and top-down Confucian standardisation have never been absolutely effective in creating a unified and harmonious religious life in Vietnam. State-building and development definitely require 
the unified interests of all partners, state, elite and commoners. During the process, state-driven notational system, ritual and shared experience have always worked inclusively to generate and maintain the unified national interests that ensure victory over any internal or external challenge. As Vietnamese people say, "You can't do anything, even what seems easy, when it is rejected by the commoners; conversely, when you have the commoners' agreement and care, you can do everything, even work that is considered a thousand times more difficult." ${ }^{21}$

\section{CONCLUSION}

Culture is "not something given but something to be gradually and gropingly discovered" by members of a society (Sapir 1949). "Much culture, however, is neither strongly institutionalised nor strongly ideologised. It exists instead as a process of pragmatic interpretation and reinterpretation" (Weller 1987: 7). The Vietnamese have built a way to deal with diversity, ambiguity and even external threats by restructuring the commoners' basic faith(s) and rituals and by utilising them to create a shared experience and empathy. It is true that all religions being absorbed and re-constructed mainly by social discourses and in a manner that is reasonable are undoubtedly sustainable. Consequently, any oppressive force imposing its power will inevitably fail.

This research finds out that state-centralised agenda had never achieved the ultimate goal of state-building in Vietnam, instead, there always have been needs to find a neutral area somewhere in between the state and the common people such that state interests and the desires of the commoners could meet, mutually make compromise and allow themselves to be fused together. The state has attained a highly integrated culture in both sacred and profane domains, thanks to the inclusive "bottom-up" agenda which is probably initiated and lead by bureaucrats and elites. Vietnam's long-term experience of de-sinicisation and quest for state-building have tied people together, regardless of social and religious differences. Bureaucrats, under the assistance of the elites, have strived to benefit from such a consciousness by transforming it into a source of harmonisation and tolerance which cultivate the inclusive mind in each person. External threats, at a certain level, turns out to be a "means" and "driving force" for facilitating internal solidarity and sharpening the community's sense of need for state-building. In such a background, Vietnam has successfully created a common platform for many religions and ideologies to live peacefully and harmoniously in a certain multicultural environment. 
On the other hand, the people of Vietnam are able to avoid extreme responses in dealing with the challenges of otherness by cultivating toleration (or appreciation) for pluralism through the creation of common rituals, which are the result of harmonious absorption and incorporation of Confucianism, Buddhism, Taoism and indigenous wisdoms. From the Vietnamese point of view, cultural diversity, including diverse religious philosophies, is a kind of "social capital." As James S. Coleman put it, "social capital is defined by its function. It is not a single entity, but a variety of different entities having two characteristics in common: They all consist of some aspect of social structure, and they facilitate certain actions of individuals who are within the structure" (Coleman 1990: 302). Vietnam's history of facilitating a harmonious mindset is also the history of building and protecting the state. Because of this, it tends to obscure the state's indigenous philosophy as well as its principles and modes of operation.

Religious diversity is undoubtedly a reflection of cultural diversity. Religious diversity can exist and develop only through a tolerant spirit and religious tolerance in particular. Religious tolerance is a special premise of a multicultural world where different peoples, leaders and civil societies acknowledge and respect the religious faiths and practices of different groups from different backgrounds. From diversity to harmonisation and tolerance, the Vietnamese people are culturally empowered by their tradition and values, and at the same time this process nurtures the mind of the nation and ensures her vigour, especially when Vietnam contemporarily reshapes and promotes her socio-cultural domains such as education (i.e., school culture and liberal ideology), social progress (i.e., social welfare and social equality), and cultural revitalisation (i.e., identity and cultural heritage preservation).

\section{ACKNOWLEDGEMENTS}

This research is funded by the Vietnam National University-Ho Chi Minh City (VNU-HCM) under grant number A2018-18b-01.

\section{NOTES}

* Vo Van Sen is Professor in History and the Former President of the University of Social Sciences and Humanities, Vietnam National University - Ho Chi Minh City. He is an expert on the History of Vietnam, Contemporary History of Vietnam, Economic History of Vietnam, the Vietnam War, and History of Vietnamese Culture. In addition, 
he has served as a member of the National Council on Political Theory of the Central Committee since 2016. He acquires rich experiences having assumed over 20 major positions in well-known academic affiliations such as Association of Vietnamese Historians; Korean Studies Association in Southeast Asia (KSASA), Australia; among many others. He was a visiting scholar at the Harvard-Yenching Institute during the academic year 1992-1993; and from 1998 to 2000, he was a visiting professor at the Faculty of Foreign Languages and Asian Studies, Nagoya University of Commerce and Business Administration, Japan. He holds the authorship and co-authorship of over 60 books and papers published in Vietnamese as well as in English. Prof. Dr. Vo Van Sen's expertise in his field of research has made him a well-known historian in contemporary Vietnam.

** Nguyen Ngoc Tho is Associate Professor in Cultural Studies, majoring in East Asian and Vietnamese folklore and social ritual studies. He concentrates on Confucian impacts in rituals, customs, and daily life of the Vietnamese and ethnic Chinese peoples under the East Asian perspective. He obtained his $\mathrm{PhD}$ degree in Vietnam National University Ho Chi Minh City, was a visiting scholar to Sun Yat-sen University in 2008, the HarvardYenching Institute during the 2017-2018 academic year and Harvard University's Asia Center in 2018-2019. He is currently visiting research scholar at Boston University where he conducts his research on Social rituals of the ethnic Chinese community in contemporary Vietnam. Nguyen Ngoc Tho is the author of four books and more than 40 journal articles published in Vietnam, China, Korea, Taiwan, Thailand, Europe and the United States. He holds the co-authorship of dozen other books, book chapters and journal articles. He is also a member of the Standing Committee of The National Foundation for Science and Technology Development (NAFOSTED) Vietnam National Council of Science and Technology in Culture, Arts, and Tourism.

1 Buu Son Ky Huong is a synthetic religion founded by Doan Minh Huyen (1807-1856) in 1849 in Chau Doc, An Giang province. Currently, there are around 15,000 followers in the Mekong River Delta (see more Ho Tai 1983: 20-27).

2 Tu An Hieu Nghia is a synthetic religion under a branch of Buu Son Ky Huong that combines Mahayana Buddhism, Lin-chi tsung 臨濟宗, Tiāntāi-zōng 天台宗, Confucianism, Taoism, ancestor worship and patriotism. It was founded by Ngo Loi (1831-1890) in Oc Eo village, Tinh Bien District, An Giang province. There are around 80,000 followers in Southern Vietnam nowadays (see more Ho Tai 1983: 3, 12, 66, $146,177)$.

3 Also called Hoahao Buddhism, Hoahaoism was founded in 1939 by Huynh Phu So (1919-1947) in Hoa Hao village, Tan Chau district, An Giang province. Hoahaoism continued Buu Son Ky Huong's philosophy; however, it adjusted the structure. Hoahaoism took Mahayana Buddhist philosophy as the foundation and added ancestor worship (see Ho Tai 1983: 17-19, 26-37, 125, 170; also Tran 2001: 472-475).

4 Caodaism is a synthetic religion that was founded by Ngo Van Chieu (1878-1932) in Tay Ninh, 100 kilometers northwest from Ho Chi Minh City. Caodaism was constructed on the foundation of Buddhism, Confucianism, Taoism, ancestor worship, Catholicism and other religions. There are around 5 million followers living in the Central and Southern Vietnam (see Tran 2001: 559-573; see more Ho Tai 1983: 77-78, 100; and Dutton and Werner 2012: 429-30). 
5 Yi Kuan Tao is a Chinese synthetics religion that was transmitted to Vietnam by overseas Chinese during 1980s (Truong 2016: 451).

6 Jehovah's Witnesses is a Western religion that was transmitted to Vietnam in 1935 by a French priest, Frank Rice, from Australia (Truong 2016: 525).

7 Minh Su is a synthetic religion that originated in China, was disseminated to Vietnam in the middle of the 19th century, and officially acknowledged by Vietnamese government in 2007 (Truong 2016: 564).

8 Ha Mon is an expanded and localised religion of Catholicism in Kon Tum (Central Highlands) that was founded in the end of the 20th century.

9 Ethnic Khmers in Vietnam practice Theravada Buddhism while ethnic Chinese practice Mahayana Buddhism.

10 The Central Vietnamese in the 17th century. North Vietnam was called Tonkin and Central and South Vietnam was called Cochinchina.

11 The term was first used by Turner, V. (1966), The ritual process: structure and antistructure, 96-97, 105, 109 (Rochester/New York: The Lewis Henry Morgan Lectures and The University of Rochester).

12 In Vietnam, hero worship has been a significant part of traditional popular religions. Some cults were formed by state, such as Ho Chi Minh cult in late 20th century, while others by commoners such as Hai Ba Trung cult (from the first century) and Saint Tran Hung Dao cult (after 13th century). See Pham Quynh Phuong (2009). However, people of latter periods mingled two sources together; therefore, these cults can be read both from the top down and from the bottom up (Ho Tai 1995; Pham 2009).

13 Mau Tu Ly Hoac Luan 牟子理惑論, or Mou-zi on the Settling of Doubts, supposedly contains an autobiographical introduction, 37 articles of dialogue between Mou-zi and an unnamed Chinese critic(s) questioning Buddhist practices, and a postscript in which the critic(s) converts to Buddhism (Thich Minh Tue 1993, History of Buddhism in Vietnam, 68 (Ho Chi Minh City: Association of Buddhism).

14 Trung quân - ái quốc: loyalty-patriotism dualism (忠於君、愛於國).

15 A synthetistic sect founded by Nguyen Thanh Nam (1910-1990) in the mid-20th century in Ben Tre province. The Coconut Sect claims the policy of religious integration and synthesis, especially Buddhism and Catholicism. The Vietnamese Government has yet to acknowledge the Coconut Sect as a religion. Currently, it is considered as a historical legacy rather than a living sect.

16 “Sát tả bình Tây" (殺左平西): “Sat Ta" means "killing the Catholics or the heterodox followers," and "bình Tây" means "defeating French colonists." The Sat Ta Binh Tay movement was also called the Văn Thân movement. It broke out in 1864 during an imperial examination. Confucian scholars protested against the Mau Than Treaty (1862) between Nguyen dynasty and the French. According to the Treaty, the Nguyen dynasty relinquished three provinces to the French. In 1870, three priests-PierreMarie Gendreau, Jean-Denis Gauther and Joseph-Hyacinthe Sohier-submitted to the royal court a proposal that would prevent the discrimination against Catholicism (Tả đạo meaning negative religion) and Catholics ("Tả dân" meaning "negative people"). The royal court passed the proposal (Quốc sử quán triều Nguyễn or Nguyen Dynasty Institute of History), Đại Nam thực lục (Annals of Đại Nam), vol. 7, Giao duc Publishing House,1149. The remnant of the movement was then boycotted because of 
its harsh treatment towards the normal Catholics. It was finally replaced by the Can Vuong movement (Aid the King Movement) in 1885 (see also Tran 2001: 530).

17 The Vietnamese translation is "Không Nho mà không Nho, không Nho mà là Nho."

18 The Chinese translation is “君非君臣非臣君臣皆共樂; 父不父子不子父子是同歡”; The English is "[When] the king does not act like a king, the minister does not act as a minister, [then] king and minister [can] all share in common enjoyment; [when] father does not act like a father, the son does not act like a son, [then] father and son [can] share in common happiness" (fieldwork note, 2016).

19 The Chinese translation is 明德儒教大道.

20 See https://ctext.org/liji/da-xue.

${ }^{21}$ The Vietnamese original proverb is "Dễ trăm lần dân không cũng chịu; Khó vạn lần dân liệu cũng xong."

\section{REFERENCES}

Baldanza, K. 2013. De-civilizing Ming China's southern border: Vietnam as lost province or barbarian culture. In Chinese history in geographical perspective, eds. Du, Y. and Kyong-McClain, J., 55-70. Lanham, MD: Lexington Books.

Buttinger, J. 1968. Vietnam: A political history. New York: Praeger.

. 1972. A dragon defiant: A short history of Vietnam. New York and Washington, DC: Praeger Publishers.

Byrne, P. 2011. A philosophical approach to questions about religious diversity. In The Oxford handbook of religious diversity, ed. Meister, C. C., 29-41. Oxford: Oxford University Press. https://doi.org/10.1093/oxfordhb/9780195340136.003.0003

Cao, T. T. 1996. Confucianism in Gia Dinh (South Vietnam). Ho Chi Minh: Ho Chi Minh City Publishing House. https://doi.org/10.33879/amh.2019.123-1902.003

Coleman, J. S. 1990. Foundations of social theory. Cambridge: Harvard University Press.

Dao, D. A. 1938. An outline of Vietnamese cultural history. Sai Gon: Bon Phuong Publishing House.

Duara, P. 1988. Superscribing symbols: The myth of Guandi the Chinese god of war. Journal of Asian Studies 47 (4): 778-795. https://doi.org/10.2307/2057852

Duong, N. D. 2004. An exploration of Vietnamese Confucian spirituality: The idea of the unity of the Three Teachings (Tam giao dong nguyen). In Confucian spirituality, vol. 2, eds. Tu, W-m. and Tucker, M. E., 289-318. New York: Crossroad Publication Company.

Durkheim, E. 1995 [1912]. The elementary forms of religious life. New York: Free Press.

Dutton, G. E. and Werner, J. S. 2012. Sources of Vietnamese tradition. New York: Colombia University Press.

Ellis, R. J. 2015. Pluralism. In International encyclopedia of the social and behavioral sciences, 2nd ed., ed. Wright, J. D., 232-235. New York: Elsevier.

Faure, D. 1999. The emperor in the village: Representing the state in South China. In State and court ritual in China, ed. McDermott, J. P., 267-98. Cambridge: Cambridge University Press. 
Feuchtwang, S. 1992. The imperial metaphor: Popular religion in China. New York: Routledge.

Fitzgerald, C. P. 1972. Chinese expansion by land: Vietnam. In The southern expansion of the Chinese people, ed. Fitzgerald, C. P., 19-38. London: Barrie \& Jenkins.

Gadamer, H-G. 1975 (1960). Truth and method. New York: Continuum.

Giran, P. 1904. Psychologie du people annamite. Le caractère national. L'évolution historique, intellectuelle, sociale et politique. Paris: Ernest Leroux.

Gosselin, C. 1904. L'empire d'Annam. Paris, Perrin. Nguyen Thua Hy translated and printed in Traditional Vietnamese culture: A viewpoint. Hanoi: Thong Tin and Truyen Thong Publishing House.

Ho Tai, H. T. 1983. Millenarianism and peasant politics in Vietnam. Cambridge, MA: Harvard University Press. https://doi.org/10.7591/9781501718991-017 .1995. Monumental ambiguity: The state commemoration of Ho Chi Minh. In Essays into Vietnamese pasts, eds. Taylor, K. and Whitmore, J., 272-88. Ithaca, New York: Cornell University, Southeast Asia Program Publications.

Holmgren, J. 1980. Chinese colonization of Northern Vietnam - Administrative geography and political development in the Tonking Delta, first to sixth centuries A.D. Canberra: Australian National University Press.

Katz, P. R. 2007. Orthopraxy and heteropraxy beyond the state - Standardizing ritual in Chinese society. Modern China 33 (1): 72-90. https://doi.org/10.1177/ 0097700406294769

Lee, K. C. 2013. Golden Dragon and Purple Phoenix - The Chinese and their multi-ethnic descendants in Southeast Asia. Singapore: World Scientific. https://doi.org/10.1142/8357

Levine, D. N. 1985. The flight from ambiguity: Essays in social and cultural theory. Chicago: University of Chicago Press.

Marbaniang, D. 2007. Theology of religions: Pluralism, inclusivism, exclusivism. Unpublished paper. https://www.academia.edu/38300310/Theology_of_Religion _Pluralism_Inclusivism_Exclusivism (accessed 25 July 2019). https:// $\overline{\text { doi.org/10 }}$ .1515/ebr.exclusivisminclusivismpluralism

Ngo, S. L. 1697 (2006). Dai Viet Su ky toan thu (大越史記全書). Hanoi: Van hoc Publishing House.

Nguyen, D. L. 2007. The tolerance in Vietnamese beliefs and religions. Cong san Journal, http://www.tapchicongsan.org.vn/Home/Tieu-diem/2007/1113/Tinh-khoandung-cua-tin-nguong-ton-giao-o-Viet-Nam.aspx (accessed 20 October 2018). https://doi.org/10.3125/rsr.v29i5.1462

Nguyen, H. D. 1995. History of Buddhism in Dang Trong (Cochinchina). Ho Chi Minh: Ho Chi Minh City Publishing House.

Nguyen, N. T. 2016. Confucianism and human education in contemporary Vietnam. International Communication on Chinese Culture 3 (4): 645-671.

. 2017. The cult of Thien Hau in the Mekong River Delta. Hanoi: National Politics Publishing House.

Nguyen, Q. and Phan, C. T. 1991. Village fine-arts. Hanoi: Fine-Arts Publishing House.

Nguyen, T. H. 1994. The 19th Vietnamese people under foreigners' eyes. In The traditional values and the contemporary Vietnamese people, vol. 1. Hanoi: The Gioi Publishing House. 
Nguyen, T. N. 2016. Zen Buddhism of Tue Trung Thuong Si and Datsetz Teitaro Suzuki: Similarities from the view of Edmund Husserl's phenomenology. In Japan: Acculturation, 111-143. Ho Chi Minh City: Vietnam National University Press.

Nguyen, V. H. 1996. Contribution to the research on Vietnamese culture, vol. 2. Hanoi: Social Sciences Publishing House.

Okholm, D. L. and Philips, T. 1996. Four views on salvation in a pluralistic world. Grand Rapids: Zondervan Publication.

Pham, Q. P. 2009. Hero and Deity - Tran Hung Dao and the resurgence of popular religion in Vietnam. Bangkok: Mekong Press.

Phan, H. C. 1961. Lịch triều hiến chưong loại chí. Khảo mục chí (歷朝憲章類誌。考目 志). Hanoi: Su Hoc Publishing House.

Phan, N. 2006. The contact of Vietnamese culture with French culture. Hanoi: Van Hoa Thong Tin Publishing House and Institute of Cultural Studies. . 2010. Vietnamese cultural identities. Hanoi: Van Hoc Publishing House.

Richey, J. L. 2013. Confucius in East Asia: Confucianism's history in China, Korea, Japan and Việt Nam. Key Issues in Asian Studies, no. 13, The Association for Asian Studies, Ann Arbor. https://doi.org/10.1111/rsr.12116 4

Quốc sử quán triều Nguyễn [National Bureau of History of the Nguyen Dynasty]. 2007. Đại Nam thực lục tập 7 [Dai Nam historical Records, vol. 7]. Hanoi: Giao Duc Publishing House. https://doi.org/10.18173/2354-1067.2015-0051

Sapir, E. 1949. The emergence of the concept of personality in a study of culture. Culture, Language and Personality 5 (3): 408-415.

Seligman, A. and Weller, R. P. 2012. Rethinking pluralism: Ritual, experience, and ambiguity. Oxford: Oxford University Press. https://doi.org/10.1093/ acprof:oso/9780199915262.001.0001

Seligman, A. et al. 2008. Ritual and its consequences: An essay on the limits of sincerity. Oxford: Oxford University Press.

Sutton, D. S. 2007. Introduction to the special issue: Ritual, cultural standardization, and orthopraxy in China - Reconsidering James L. Watson's ideas. Modern China 33 (1): 3-21. https://doi.org/10.1177/0097700406294914

Taylor, K. 1976. The rise of Đại Việt and the establishment of Thăng-long. In Explorations in the early Southeast Asian history: The origins of Southeast Asian statecraft, eds. Hall, K. R. and Whitmore, J. K., 149-181. Ann Arbor: University of Michigan. https://doi.org/10.1017/s0041977x00058742

Taylor, R. L. 1990. The religious dimensions of Confucianism. Albany: SUNY Press.

Thich, M. T. 1993. History of Buddhism in Vietnam. Ho Chi Minh: Association of Buddhism.

Tran, N. T. 2001. Discovering Vietnamese identities. Ho Chi Minh: Ho Chi Minh City Publishing House. https://doi.org/10.31276/vjste.61(1).36-40

Tran, P. T. and Hoang, V. N. 2014. Religious tolerance in the modern world. Vietnam Social Sciences Journal 9 (82): 60-66.

Truong, V. C. 2016. New Religion - the Cognition and Reality. Ho Chi Minh: Vietnam National University Press.

Turner, V. 1966. The ritual process: Structure and anti-structure. Rochester/New York: The Lewis Henry Morgan Lectures and the University of Rochester. https://doi. org/10.1126/science.168.3932.702 
Vo, V. S. and Pham, D. M. 2017. Oc Eo and Post-Oc Eo cultural tradition - The material foundation of kingdom of Funan in lower Mekong River Delta. In The values of heritage Oc Eo-An Giang in the process of economic-social development, 3-86. Ho Chi Minh City: Vietnam National University Press. https://doi.org/10.1093/ gao/9781884446054.article.t063189

von Glahn, R. 2004. The sinister way: The divine and the demonic in Chinese religious culture. Berkeley: University of California Press. https://doi.org/10.1525/ california/9780520234086.001.0001

Waley, A. 1938. The Analects of Confucius. New York: Random House.

Watson, J. L. 1985. Standardizing the gods: The promotion of Tien'hou ("empress of heaven") along the South China Coast, 960-1960. In Popular culture in late imperial China, eds. Johnson, D. G., Nathan, A. J. and Rawski, E. S., 292-324. Berkeley: University of California Press.

Weller, R. P. 1987. Unities and diversities in Chinese religion. London: Macmillan and Seattle: University of Washington Press.

Whitmore, J.K. 1985. Vietnam, Hồ QuýLyand the Ming 1371-1421. New Haven: Yale Center for International and Area Studies. https://doi.org/10.1017/s0022463400003763

Wolf, A. 1974. Religion and ritual in Chinese society. Stanford, CA: Stanford University Press.

Wolters, O. W. 1976. Le Van Huu's treatment of Ly Than Tong's reign (1127-1137). In Southeast Asian history and historiography: Essays presented to D.G.S. Hall, eds. Cowan, C. D. and Wolterss, O. W., 203-226. Ithaca, NY: Cornel University Press.

Womack, B. 2006. China and Vietnam: The politics of asymmetry. Cambridge and New York: Cambridge University Press. 